\title{
Multisystem Inflammatory Syndrome in Children (MIS-C) with COVID-19
}

\section{COVID-19 Ilişkili Çocuklarda Multisistem Inflamatuar Sendromu (MIS-C)}

\author{
Ergin Çiftçi'(i D), Gül Arga'(iD), Esra Çakmak Taşkın'(iD ), Hatice Kübra Konca'(iD), Halil Özdemir'(iD) \\ ${ }^{1}$ Division of Pediatric Infectious Diseases, Department of Pediatrics, Ankara University School of Medicine, Ankara, Turkey
}

\begin{abstract}
Cite this article as: Çiftçi E, Arga G, Çakmak Taşkın E, Konca HK, Özdemir H. Multisystem inflammatory syndrome in children (MIS-C) with COVID-19. J Pediatr Inf 2020;14(4):e243.
\end{abstract}

A seven-year-old girl was brought with complaints of fever, abdominal pain and rash. She was referred to our hospital with acute appendicitis by the hospital she first applied to. It was learned that the girl's grandfather had COVID-19 a month ago. In the examination of the patient, fever was measured as $38.5^{\circ} \mathrm{C}$, redness was seen in both conjunctiva and erythema which was more prominent on the cheeks was found on the face. She had cracking and peeling on her lips, a red strawberry tongue appearance, and widespread erythema on her trunk. There was tenderness in the left lower quadrant of the abdomen. Laboratory findings were WBC: $8920 / \mathrm{mm}^{3}, \mathrm{Hb}: 11.6 \mathrm{~g} / \mathrm{dL}, \mathrm{PLT}: 50,000 /$ mm³. CRP: $93.4 \mathrm{~g} / \mathrm{L}$, D-dimer: $8671 \mathrm{ng} / \mathrm{mL}$, ferritin: $289 \mathrm{ng} / \mathrm{mL}$, and albumin: $2.71 \mathrm{~g} / \mathrm{L}$. The patient's SARS-CoV-2 PCR was negative, but SARS-CoV-2 antibody was found to be positive. Echocardiography was found to be normal. Multisystem inflammatory syndrome in children (MIS-C) with COVID-19 was considered. The patient received IVIG $2 \mathrm{~g} / \mathrm{kg}$ as a single dose. Prednisolone $2 \mathrm{mg} / \mathrm{kg} / \mathrm{d}$, aspirin $3.5 \mathrm{mg} / \mathrm{kg} / \mathrm{d}$, pantoprazole and piperacillin-tazobactam were also started. The patient's fever resolved; all clinical signs regressed. The antibiotic therapy was stopped on the seventh day of her hospitalization, and the patient was discharged with prednisolone tapering in 3 weeks.

Children can usually survive COVID-19 disease without any problems. On the other hand, MIS-C can be seen in some children after infection. Although it was initially thought to have characteristics similar to Kawasaki disease and toxic shock syndromes, it is now accepted as a distinct entity. MIS-C is thought to be an immunological reaction as it occurs weeks after SARS-CoV-2 infection. MIS-C manifests itself in a patient with SARS-CoV-2 exposure history, PCR, antigen or antibody positivity, who has fever, elevated inflammatory markers, and involvement of at least two organ systems (heart, lung, kidney, skin, hematological, gastrointestinal and neurological). However, diseases that may cause a similar clinical picture in patients should be excluded. The disease can be fatal if not recognized and treated appropriately. The prognosis is generally good with IVIG and corticosteroid doses depending on the severity of the disease.

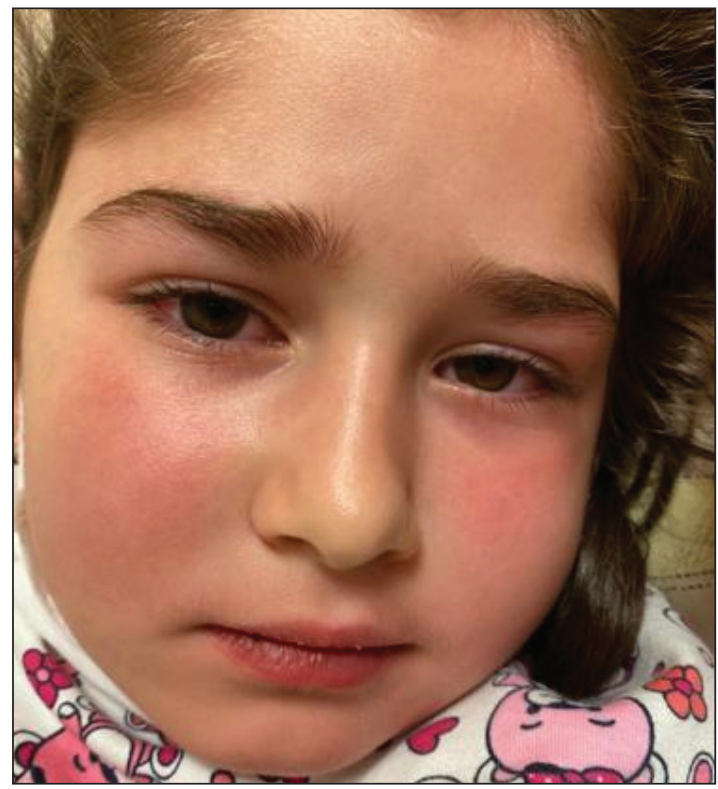

Correspondence Address/Yazışma Adresi

Ergin Çiftçi

Ankara Üniversitesi Tıp Fakültesi,

Çocuk Sağlığı ve Hastalıkları Anabilim Dalı,

Çocuk Enfeksiyon Hastalıkları Bilim Dalı,

Ankara-Türkiye

E-mail: erginciftci@gmail.com 